\title{
FTIR analysis and quantification of phenols and flavonoids of five commercially available plants extracts used in wound healing
}

\author{
Análise por FTIR e quantificação de fenóis \\ e flavonóides de cinco produtos naturais \\ disponíveis comercialmente utilizados \\ no tratamento de feridas
}

\author{
Renata Nunes Oliveira ${ }^{1}$, Maurício Cordeiro Mancini ${ }^{1}$, \\ Fernando Cabral Salles de Oliveira ${ }^{2}$, Thayse Marques Passos ${ }^{3}$, Brid Quilty ${ }^{3}$, \\ Rossana Mara da Silva Moreira Thiré ${ }^{4}$, Garrett Brian McGuinness ${ }^{5}$
}

\author{
${ }^{1}$ Chemical Engineering Department, Federal Rural University of Rio de Janeiro, Br. 465, km 7, Z.C.: 23897000, Sero- \\ pédica/RJ, Brazil. \\ e-mail: renatanunes.ufrrj@gmail.com \\ ${ }^{2}$ School of Pharmacy, Royal College of Surgeons in Ireland, Dublin 2, Dublin, Ireland \\ ${ }^{3}$ School of Biotechnology, Dublin City University, Glasnevin, Dublin, Dublin 9, Ireland \\ ${ }^{4}$ Materials and Metallurgical Engineering Department, Federal University of Rio de Janeiro, COPPE/UFRJ, Cid. Univer- \\ sitária - Technology Center - Bl. I, S. I-245, Ilha do Fundão, RJ/RJ, Z.C.: 21941-972, POBox: 68505 Brazil. \\ ${ }^{5}$ Centre for Medical Engineering Research, Dublin City University, Glasnevin, Dublin, Dublin 9, Ireland. \\ e-mail: mancinimc@gmail.com; salles3035@gmail.com, thaysemp@gmail.com, brid.quilty@dcu.ie, ros- \\ sana@metalmat.ufrj.br; Garrett.McGuinness@dcu.ie
}

\begin{abstract}
Natural products are used in wound healing in order to prevent infection. Propolis is a well known antimicrobial with phenolic compounds and flavonoid content which vary according to the propolis origin. Besides propolis (from both Brazilian and UK sources), pomegranate, dragon's blood and sage are possible antimicrobials to be used in biomaterials. The goal of this work was to analyze the amount of phenols and flavonoid compounds in these natural products, their antioxidant activities and the bonds present by FTIR. The FTIR analysis revealed the presence of active compounds in all drug samples. The phenols quantification showed that Brazilian propolis was rich in phenols compared to the other drugs, followed by pomegranate and UK propolis. UK propolis was the most rich in flavonoids, which is expected on account of its origin. Pomegranate, UK propolis and Dragon's blood presented the highest antioxidant activity. All samples presented antioxidant activity $>82 \%$.
\end{abstract}

Keywords: propolis, pomegranate, sage, dragon's blood.

\section{RESUMO}

Produtos naturais são classicamente usados em tratamento de feridas, para prevenção de infecção. A Própolis é um agente antimicrobiano natural bem estabelecido, o qual contém compostos fenólicos e flavonoides, cujos teores variam conforme a sua origem. A Própolis de origem britânica e a de origem brasileira, a romã, o sangue de dragão e a sálvia são agentes antimicrobianos utilizados em biomateriais. O objetivo deste trabalho foi a análise do teor de fenóis e flavonoides, da atividade antioxidante das mesmas e das ligações químicas presentes nesses compostos, usando FTIR. A análise de FTIR revelou a presença desses compostos ativos em todos os produtos analisados. A própolis brasileira é rica em fenóis comparada aos outros fitoterápicos, seguido de romã e própolis britânica. A própolis britânica é rica em flavonoides devido à sua origem. Romã, própolis britânica e sangue de dragão apresentaram as maiores atividades antioxidantes. Todas as amostras apresentaram atividade antioxidante superior a $82 \%$.

Palavras-chave: própolis, romã, sálvia, sangue de dragão. 


\section{INTRODUCTION}

Natural products have been used in the treatment of several diseases for centuries [1]. Wounds are among the diseases that have been treated with several natural products. The products applied to wound healing would have anti-inflammatory, antimicrobial, antifungal and antiviral activities [2].

According to Kumar and collaborators (pg. 104, 1. 41-44 [1]), healing "involves platelet aggregation and blood clotting, formation of fibrin, an inflammatory response to injury, alteration in the ground substances, angiogenesis and re-epithelialization". To heal, the wound / the burn needs to be free of infection. In order to prevent infection in burns for example, synthetic drugs have been developed to kill bacteria and fungus, among the most used ones there are antibiotics, chlorhexidine and silver [3]. Among the natural products to treat burn wounds there are honey, propolis, Aloe vera, Calendula officinalis, etc [4]. In addition, the inflammation process leads to the accumulation of reactive oxygen species at the wound site, which attack proteins leading to tissue injury. In order to prevent it, there are natural products which have antioxidant activity $[5]$.

Natural products have been used in the treatment of several diseases for centuries, among them, wound healing [1]. To heal, the wound or burn needs to be free of infection. To achieve this, synthetic antimicrobials and natural products can be used, e.g. honey, propolis, Calendula officinalis, etc [4]. These products should be antimicrobial and anti-inflammatory compounds. They should also present antioxidant activity, since the inflammation process leads to the accumulation of reactive oxygen species at the wound site, which attack proteins and damage the cells [5].

Crotton lechleri (Dragon's blood) is a red resin used in folk medicine to treat wounds. There are numerous components in its composition, but its active compounds would be terpenoids, flavonoids and phenols [6]. Phenolic compounds and flavonoids can be considered as antioxidant substances by acting as reducing agents and by free-radical scavenging, since they donate hydrogen to free-radicals [7].

Propolis, Propolis mellifera, a bee based product, is used to protect the hive from microbes and from other insects [8] [9]. Propolis has antibacterial, anti-fungal, anti-viral and anti-inflammatory activities [10] [11]. Propolis composition varies with its origin / local flora, but phenolic compounds and flavonoids are usually part of its composition [12]. Flavonoids, besides phenolic substances, e.g. caffeic acid phenethyl ester - CAPE, and cinnamic acids derivatives, would be the ones responsible for the antioxidant, antiinflammatory, anticancer and antiviral activities of propolis [13].

Pomegranate, Punica granatum, a plant species, also has the required properties to be used in wounds [14], as well as sage, Salvia officinalis, which present various bioactive compounds to be applied on wounds [15]. Regarding pomegranate, the fruit has several medicinal properties and different parts of the fruit (peel, juice etc) can be used. Its main active compounds would be phenolic compounds [16]. Salvia species have also been used in wound treatment in folk medicine. Salvia species have anti-inflammatory, antifungal and antiseptic properties [17].

The goal of this work is to analyze the compounds effective bonds, the amount of active compounds and the anti-oxidant activity of five natural products used in wound healing, Brazilian and UK propolis extracts, pomegranate tincture, dragon's blood and sage tincture.

\section{MATERIALS AND METHODS}

The natural antimicrobials used were: Green Propolis Extract (Uniflora, Brazilian propolis, minimum of dry extract of 11\%); Propolis (BeeHealth, United Kingdom, 50\%); Pomegranate tincture (Atomo, 50\%), Sage Tincture (Fushi Wellbeing, 25\%) and Dragon's blood (Amazon Therapeutics Laboratories, 100\%).

The Fourier-Transform Infrared Spectroscopy (FTIR) analysis of the drugs was performed on a drop of each drug. The FTIR analysis was done on the liquid extracts. The equipment used was Perkin Elmer Spectrum GX, 16 scans per samples in the region of (4000-650) $\mathrm{cm}^{-1}$.

To evaluate the amount of flavonoids present in the drugs extracts, $0.5 \mathrm{~mL}$ of the diluted drugs $(1 \mathrm{mg} / \mathrm{mL})$ was mixed with $0.5 \mathrm{~mL}$ of $2 \% \mathrm{AlCl}_{3}$ (Sigma-Aldrich) ethanolic solution in the dark (triplicates). To plot a standard curve, $0.5 \mathrm{~mL}$ of different solutions of quercetin - "Q" (Sigma-Aldrich, range of $0 \mu \mathrm{g}-$ $125.00 \mu \mathrm{g}$ ) in ethanol was mixed with $0.5 \mathrm{~mL}$ of $2 \% \mathrm{AlCl}_{3}$ ethanolic solution in the dark. After incubation for $45 \mathrm{~min}$, the solutions were analyzed in the UV-Vis spectrophotometer (VWR, UV-3100PC Spectrophotometer), wavelength of $415 \mathrm{~nm}$ [18].

The total amount of phenolic compounds in the tinctures / extracts was quantified according to the amount of gallic acid (Sigma-Aldrich) equivalents in the drugs' dilutions $(1 \mathrm{mg} / \mathrm{mL})$. A standard curve was plotted where alcoholic dilutions of gallic acid - "GA" $(0.05-0.25 \mathrm{mg} / \mathrm{mL})$ were analyzed by UV-Vis spec- 
trometer at wavelength of $765 \mathrm{~nm}$. An aliquot of $0.1 \mathrm{~mL}$ of each solution (Gallic acid or drugs' dilutions), was mixed with $0.5 \mathrm{~mL}$ of solution Folin-Ciocalteu (Sigma-Aldrich) for $5 \mathrm{~min}$ in the dark. These solutions were then mixed with $0.4 \mathrm{~mL}$ of solution $2 \% \mathrm{Na}_{2} \mathrm{CO}_{3}$ (Sigma-Aldrich) in the dark and incubated for $2 \mathrm{~h}$ before analysis [18].

The 1,1-Diphenyl-2-Picryl-Hydrazyl (DPPH) scavenging activity, equation 1, was measured by mixing $0.5 \mathrm{~mL}$ of the drugs' dilutions $\left(\mathrm{A}_{1}\right)$ with $0.5 \mathrm{~mL}$ of the $100 \mu \mathrm{M}$ DPPH alcoholic solution in the dark. The reference sample $\left(\mathrm{A}_{0}\right)$ was $1.0 \mathrm{~mL}$ of the $100 \mu \mathrm{M}$ DPPH solution. After incubating for $15 \mathrm{~min}$, they were analyzed in the UV-Vis spectrometer (VWR, UV-3100PC Spectrophotometer), wavelength of $517 \mathrm{~nm}$ [18].

$\operatorname{DPPH}(\%)=100 *\left[\frac{A_{0}-A_{1}}{A}\right] \quad$ Eq. 1

In the set of triplicates for each drug, it was found that one sample presented experimental error. These samples were not considered for the statistical analysis. Based on duplicates, the coefficient of variation was calculated and the t-student tests were proceeded, level of confidence $95 \%$.

\section{RESULTS}

The FTIR spectra related to each studied sample are displayed in: Figure 1, spectrum related to Brazilian Propolis extract; Figure 2, spectrum related to UK propolis tincture; Figure 3, spectrum related to Pomegranate tincture; Figure 4, spectrum related to dragon's blood; and Figure 5, spectrum related to sage extract. The bands identified in each sample are displayed in Table 1.

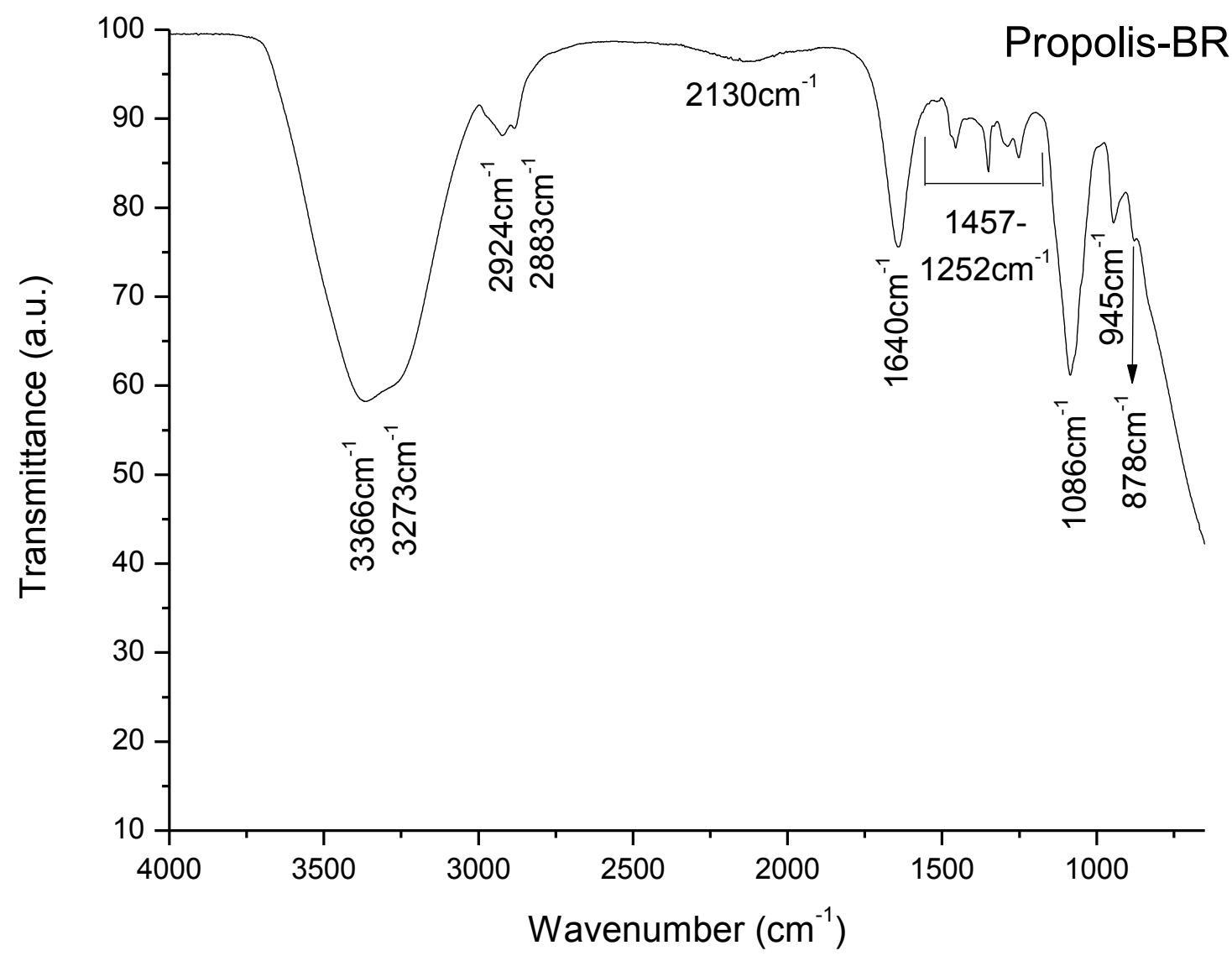

Figure 1: FTIR bands related to the Brazilian Propolis extract. 


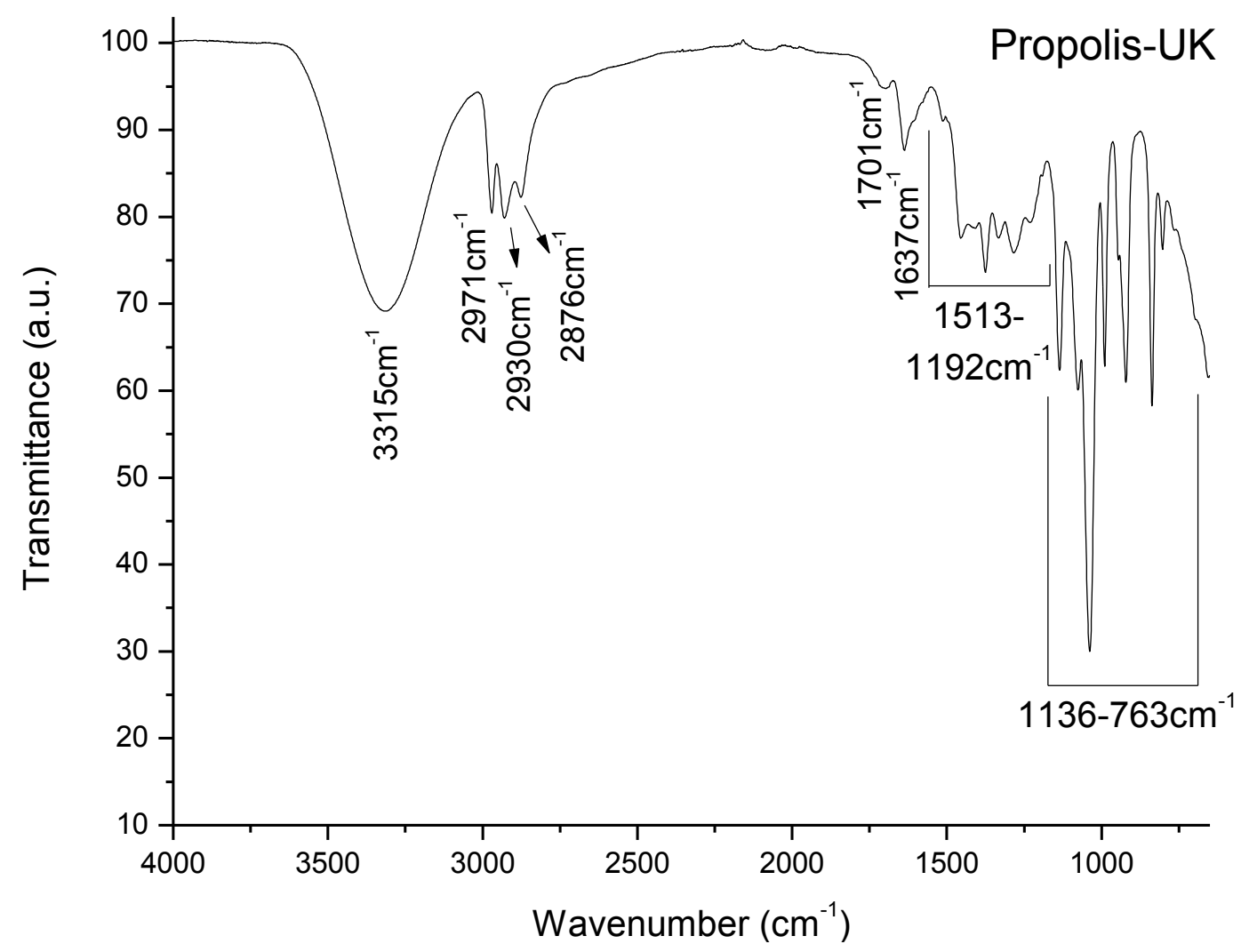

Figure 2: FTIR bands related to UK Propolis tincture.

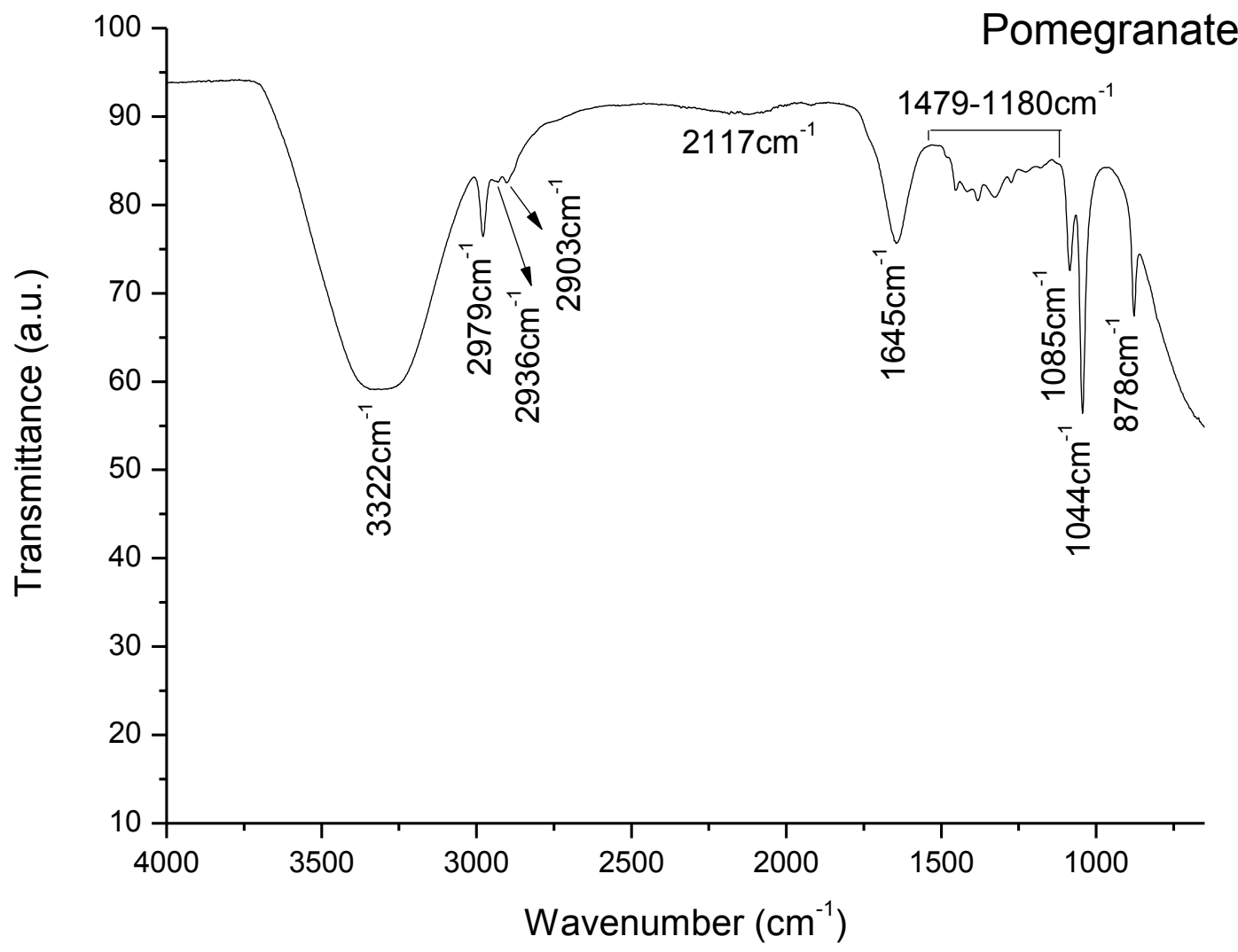

Figure 3: FTIR bands related to pomegranate tincture. 


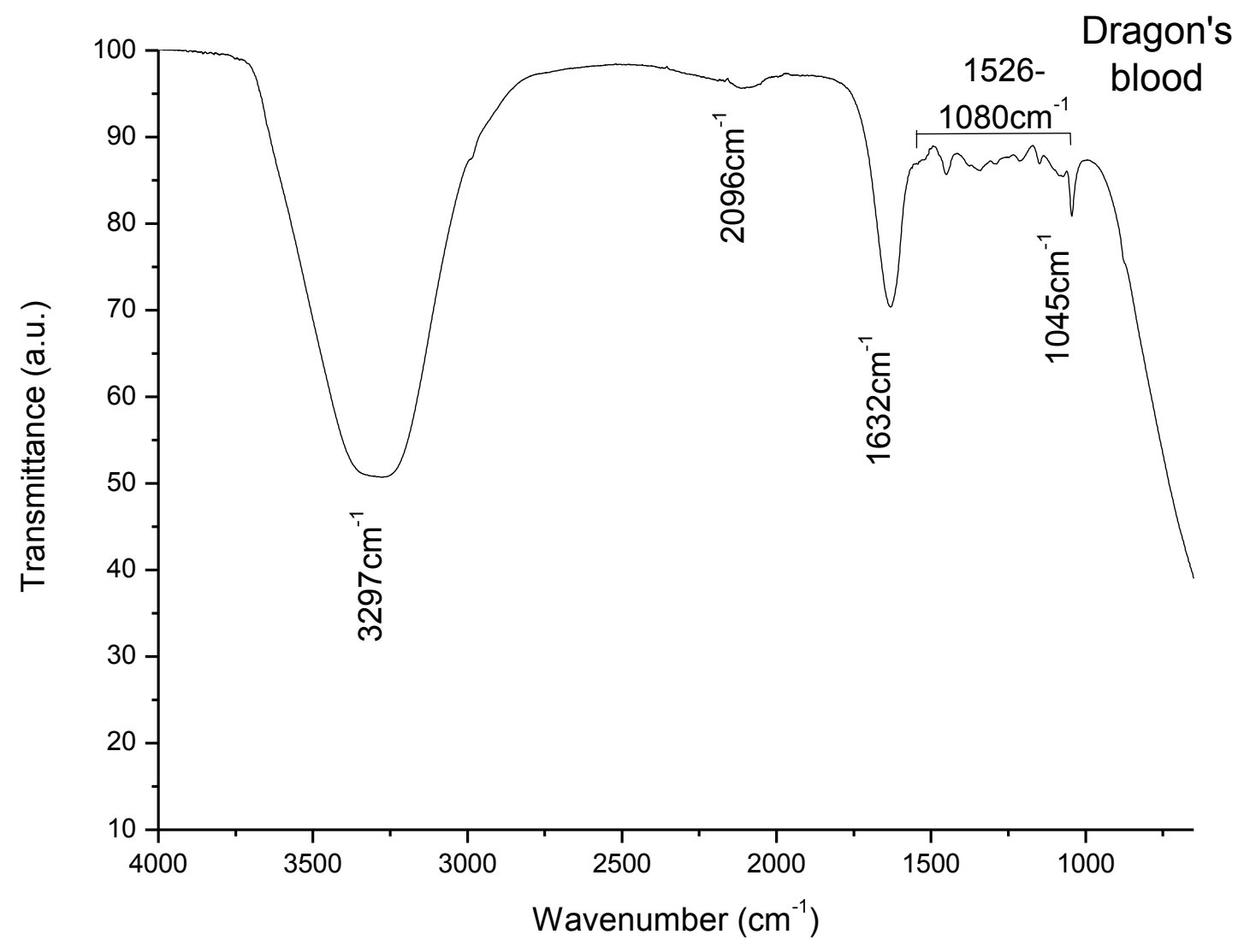

Figure 4: FTIR bands related to Dragon's blood.

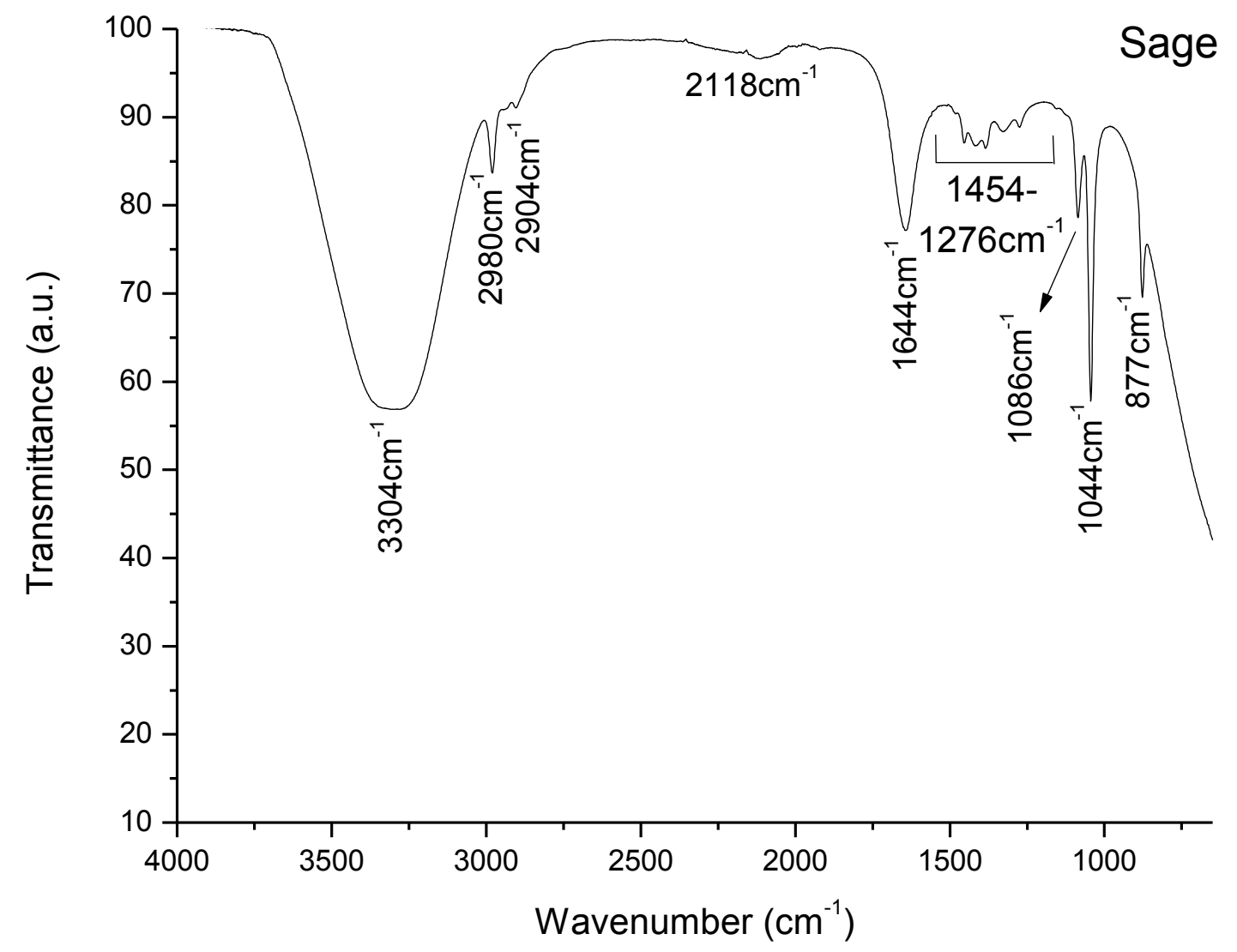

Figure 5: FTIR bands related to sage extract. 
Table 1: Identified bands in FTIR spectra of all studied samples.

\begin{tabular}{|c|c|c|c|c|}
\hline Propolis BR & Propolis UK & Pomegranate & Dragon's blood & Sage \\
\hline \multicolumn{5}{|c|}{$\left(\mathrm{cm}^{-1}\right)$} \\
\hline 3366 & 3315 & 3322 & 3297 & 3304 \\
\hline 3273 & 2971 & 2979 & 2096 & 2980 \\
\hline 2924 & 2930 & 2936 & 1632 & 2904 \\
\hline 2883 & 2876 & 2903 & 1526 & 2118 \\
\hline 2130 & 1701 & 2117 & 1450 & 1644 \\
\hline 1640 & 1637 & 1645 & 1340 & 1454 \\
\hline 1457 & 1513 & 1479 & 1291 & 1418 \\
\hline 1350 & 1454 & 1452 & 1209 & 1385 \\
\hline 1289 & 1410 & 1417 & 1149 & 1328 \\
\hline 1252 & 1375 & 1382 & 1080 & 1276 \\
\hline 1086 & 1333 & 1328 & 1045 & 1086 \\
\hline 945 & 1283 & 1274 & & 1044 \\
\hline \multirow[t]{5}{*}{878} & 1231 & 1228 & & 877 \\
\hline & 1192 & 1180 & & \\
\hline & 1136 & 1085 & & \\
\hline & 1076 & 1044 & & \\
\hline & 1039 & 878 & & \\
\hline
\end{tabular}

The amount of phenols and of flavonoids in each herbal was analyzed at the concentration of $1 \mathrm{mg} / \mathrm{ml}$ of the dry extract and the results are shown in Table 2 . The antioxidant activity of each herbal at the concentration of $1 \mathrm{mg} / \mathrm{ml}$ was also analyzed, Table 2 .

It can be observed (Figure 6) that, related to the amount of phenols, Brazilian propolis and pomegranate, as well as UK propolis and pomegranate, present approximately the same amount of phenols, and are the richest ones. No significant variance was observed. Dragon's blood present low amount of phenols compared to the previous herbals and sage has the lowest amount of phenols among the herbals studied $(p<0.05)$. With respect to flavonoids, UK propolis is the richest one. The amount of flavonoids in the other herbals was lower than that of UK propolis, where the amount of flavonoids diminished progressively according to: Brazilian propolis, pomegranate, sage and dragon's blood, respectively. All the samples' flavonoids amounts are significantly different $(\mathrm{p}<0.05)$. The DPPH scavenging activity of UK propolis, Pomegranate and Dragon's blood are identical $(\mathrm{p}>0.05)$, followed by Brazilian propolis and sage with the lowest amounts, respectively.

Table 2: Amount of active compounds in each drug. $\mathrm{Ph}=$ phenolic compounds, $\mathrm{Fl}=$ flavonoids and D.B. $=$ dragon's blood.

\begin{tabular}{c|c|c|c|c|c}
\hline Drug & Propolis-BR & Propolis-UK & Pomegranate & D.B. & Sage \\
\hline $\mathrm{Ph}(\mathrm{mg} / \mathrm{g})$ & $209.72 \pm 16.55^{\mathrm{a}}$ & $161.65 \pm 12.93^{\mathrm{b}}$ & $167.25 \pm 28.77^{\mathrm{a}, \mathrm{b}}$ & $85.88 \pm 6.67^{\mathrm{c}}$ & $57.18 \pm 0.56^{\mathrm{d}}$ \\
\hline $\mathrm{Fl}(\mathrm{mg} / \mathrm{g})$ & $28.60 \pm 0.20^{\mathrm{e}}$ & $35.80 \pm 1.76^{\mathrm{f}}$ & $14.93 \pm 1.00^{\mathrm{g}}$ & $3.03 \pm 0.04^{\mathrm{h}}$ & $7.76 \pm 0.18^{\mathrm{i}}$ \\
\hline $\mathrm{DPPH}(\%)$ & $88.23 \pm 0.25^{\mathrm{j}}$ & $92.45 \pm 0.38^{\mathrm{k}}$ & $94.17 \pm 0.10^{\mathrm{k}}$ & $94.51 \pm 0.10^{\mathrm{k}}$ & $82.95 \pm 0.03^{\mathrm{m}}$ \\
\hline
\end{tabular}

Values labelled with equal letters are not different $(\mathrm{p}<0.05)$ 

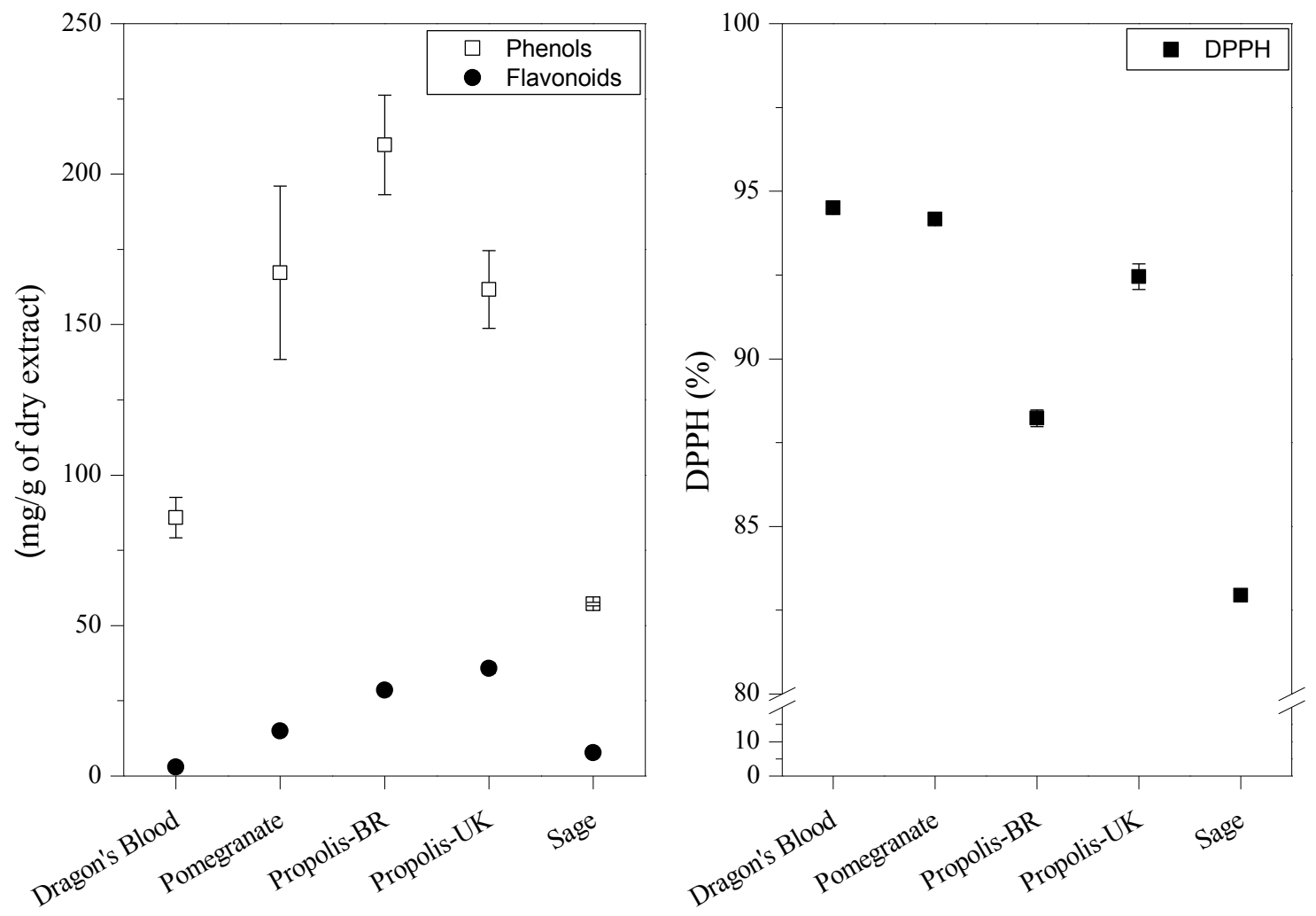

Figure 6: Phenolic compounds and flavonoids amounts of the products and anti-oxidant (DPPH) activity of the products.

\section{DISCUSSION}

Since the samples extracts were alcoholic extracts, ethanol bands could be in all FTIR spectra. Characteristic ethanol bands would be at $\sim 3687 \mathrm{~cm}^{-1}$, related to stretching vibration of O-H groups; at 2977 and $2924 \mathrm{~cm}^{-1}$, due to stretching vibration of C-H (the bands at 2994, 2977, 2924, 2904 and $2890 \mathrm{~cm}^{-1}$ would be due to stretching vibrations of $\mathrm{CH}_{2}$ and $\mathrm{CH}_{3}$ groups). The bands at $1391 \mathrm{~cm}^{-1}$ and at $1242 \mathrm{~cm}^{-1}$ would be related to $\mathrm{C}-\mathrm{H}$ bending vibration and to $\mathrm{O}-\mathrm{H}$ bending vibration respectively. The band at $1067 \mathrm{~cm}^{-1}$ would be due to CO stretching vibration and the band at $877 \mathrm{~cm}^{-1}$ would be related to C-C stretching vibration [19].

Propolis (Brazilian propolis, wax free) presented the bands showed in Figure 1. It can be observed bands at $3366 \mathrm{~cm}^{-1}$ and at $3273 \mathrm{~cm}^{-1}$, related to hydroxyl groups [20]. Bands approximately in the same range of wavelength in different propolis samples were also identified, e.g. a band at $3487 \mathrm{~cm}^{-1}$, related to stretching (v) vibration of hydroxyl groups [21] and a band at $3433 \mathrm{~cm}^{-1}$, related to $\mathrm{OH}$ wagging $(\mathrm{OH}$ of phenolic compounds) [22]. Bands at $2924 \mathrm{~cm}^{-1}$ and at $2883 \mathrm{~cm}^{-1}$ could be attributed to ethanol [19]. The band at $2130 \mathrm{~cm}^{-1}$ could not be identified. A band was found at $1640 \mathrm{~cm}^{-1}$. This band could be due to stretching vibration of $\mathrm{C}=\mathrm{C}$ groups [21], due to aromatic ring deformations [23], due to flavonoids and amino acids: stretching vibration of $\mathrm{C}=\mathrm{O}$ and of $\mathrm{C}=\mathrm{C}$, asymmetric bending vibration of $\mathrm{N}-\mathrm{H}$ [24], due to $\mathrm{C}=\mathrm{O}$ stretching vibration of caffeic acid and its derivatives [22] and due to stretching vibration of $\mathrm{C}=\mathrm{O}$ of lipids and flavonoids [20]. The band at $1457 \mathrm{~cm}^{-1}$ could be related to $\mathrm{CH}_{3}, \mathrm{CH}_{2}$, flavonoids and aromatic rings, where the vibrations would be the bending $(\delta)$ vibration of $\mathrm{C}-\mathrm{H}$ and the stretching vibration of aromatics [24] [25]. There were also found non-identified bands at $1350 \mathrm{~cm}^{-1}$ and $1289 \mathrm{~cm}^{-1}$. The band at $1252 \mathrm{~cm}^{-1}$ would be due to vibration of $\mathrm{C}-\mathrm{O}$ group of polyols, such as hydroxyflavonoids [25]. A band at $1086 \mathrm{~cm}^{-1}$ would be related to secondary alcohols [20] and/or to C-O- stretching ester group [22]. There was a non-identified band at $945 \mathrm{~cm}^{-1}$ and a band at $878 \mathrm{~cm}^{-1}$, probably related to aromatic ring vibration [22] or to ethanol [19].

In Propolis from United Kingdom (Propolis-UK), Figure 2, some bands previously described in Brazilian Propolis were also found. These were bands at: $3315 \mathrm{~cm}^{-1}\left(\mathrm{OH}\right.$ groups), $2971 \mathrm{~cm}^{-1}$ (aliphatic $\mathrm{vCH}_{2}$ ), $2930 \mathrm{~cm}^{-1}$ and $2876 \mathrm{~cm}^{-1}$ (probably related to ethanol), $1637 \mathrm{~cm}^{-1}$ (mainly due to $\mathrm{C}=\mathrm{C}$ and $\mathrm{C}=\mathrm{O}$ vibrations), $1454 \mathrm{~cm}^{-1}$ (CH and aromatic vibrations), $1283 \mathrm{~cm}^{-1}, 1231 \mathrm{~cm}^{-1}$ (probably related to $\mathrm{C}-\mathrm{O}$ of polyols), $1076 \mathrm{~cm}^{-1}$ (secondary alcohols and C-O- vibrations) and $945 \mathrm{~cm}^{-1}$. Besides the bands previously described, there were other bands encountered. A band at $1701 \mathrm{~cm}-1$, probably related to: stretching vibration of car- 
boxyl groups [21], stretching of $\mathrm{C}=\mathrm{O}$ of flavonoids and lipids [23] [24]. A band at $1513 \mathrm{~cm}^{-1}$, related to aromatic ring deformations [23] and to flavonoids and aromatic rings (stretching of aromatic $\mathrm{C}=\mathrm{C}$ ). $\mathrm{A}$ band at $1410 \mathrm{~cm}^{-1}, \mathrm{C}=\mathrm{C}$ ring stretching (which occurs in pairs at $1638 \mathrm{~cm}^{-1}$ and at $1409 \mathrm{~cm}^{-1}$ ) [22]. Bands at $1375 \mathrm{~cm}^{-}$ ${ }^{1}$ and at $1333 \mathrm{~cm}^{-1}$ were non-identified. A band at $1192 \mathrm{~cm}^{-1}$ was non-identified, although bands at $1160 \mathrm{~s}$ were considered to occur due to lipids and alcohol groups (stretching of $\mathrm{C}-\mathrm{O}$ and bending of $\mathrm{C}-\mathrm{OH}$ ) [23] [24]. A band at $1136 \mathrm{~cm}^{-1}$ related to tertiary alcohols [20]. A band at $1039 \mathrm{~cm}^{-1}$, probably related to primary and secondary alcohols [20] and to C-O- stretching ester group [22]. The bands at $990 \mathrm{~cm}^{-1}, 922 \mathrm{~cm}^{-1}$, $837 \mathrm{~cm}^{-1}$ and $803 \mathrm{~cm}^{-1}$ were not identified.

Pomegranate sample, Figure 3, revealed bands at: $3322 \mathrm{~cm}^{-1}$, probably related to -NH and bonded $\mathrm{OH}$ groups of carboxylic acids [26]; the band at $2979 \mathrm{~cm}^{-1}$ could be due to ethanol [19]; the band at $2936 \mathrm{~cm}^{-}$ ${ }^{1}$ could be related to $\mathrm{C}-\mathrm{H}$ stretching vibration of methyl and methoxy groups [27] [28] and to stretching vibration of $-\mathrm{CH}_{3}$ or $-\mathrm{CH}_{2}$ groups in carboxylic acid [26]. The band a $2903 \mathrm{~cm}^{-1}$ would be due to ethanol [19] and the band at $2117 \mathrm{~cm}^{-1}$ was not identified. The band at $1645 \mathrm{~cm}^{-1}$ could be related to $\mathrm{C}=\mathrm{C}$ stretching vibration of aromatic rings [29] [23] [21] and to the vibration of $\mathrm{N}-\mathrm{H}$ of amines, $\mathrm{C}=\mathrm{O}$ of amides and carboxylic groups [26], in addition, based on propolis analysis, this band could be related to flavonoids and amino acids, $v(\mathrm{C}=\mathrm{O}), v(\mathrm{C}=\mathrm{C}), \delta \operatorname{as}(\mathrm{N}-\mathrm{H})$ [24]. There was a non-identified band at $1479 \mathrm{~cm}^{-1}$ and there was a band at $1452 \mathrm{~cm}^{-1}$, probably due to the presence of aromatic $-\mathrm{C}=\mathrm{C}$ - bond [29] and / or to N-H bending vibration [26]. Band at $1417 \mathrm{~cm}^{-1}$ was not identified and the band at $1382 \mathrm{~cm}^{-1}$ would be related to ethanol [19]. The band at $1328 \mathrm{~cm}^{-1}$ could be related to $\mathrm{C}-\mathrm{O}$ stretching of acid groups [27] or to bending vibrations of $-\mathrm{CH}_{3}$ or $-\mathrm{CH}_{2}$ groups in carboxylic acid [26]. The bands at $1274 \mathrm{~cm}^{-1}$ and at $1228 \mathrm{~cm}^{-1}$ were not identified, although a band at $1255 \mathrm{~cm}^{-1}$ was related to $\mathrm{C}-\mathrm{O}$ acid stretching [28] and a band at $1242 \mathrm{~cm}^{-1}$ is related to ethanol [19]. The band at $1180 \mathrm{~cm}^{-1}$ could be related to $\mathrm{C}-\mathrm{O}$ stretching and $-\mathrm{OH}$ deformation of primary alcohols, the band at $1085 \mathrm{~cm}^{-1}$, to $\mathrm{C}-\mathrm{O}$ stretching and $-\mathrm{OH}$ deformation of secondary alcohols and at $1044 \mathrm{~cm}^{-1}$, to $\mathrm{C}-\mathrm{O}$ stretching and - $\mathrm{OH}$ deformation of tertiary alcohols [28], the last one could also be attributed to C-N stretching vibration [26]. The band at $878 \mathrm{~cm}^{-1}$ could be due to aromatic ring vibration [22] or to ethanol [19].

Analysing Dragon's Blood, Figure 4, there were bands at $3297 \mathrm{~cm}^{-1}$, possibly due to OH groups vibrations [20]; at $2096 \mathrm{~cm}^{-1}$ is a non-identified band; at $1632 \mathrm{~cm}^{-1}$, it could be related to stretching vibration of aromatic $\mathrm{C}=\mathrm{C}$; a "shoulder" at $1526 \mathrm{~cm}^{-1}$ was not identified; at $1450 \mathrm{~cm}^{-1}$ could be due to stretching vibration of aromatic $\mathrm{C}=\mathrm{C}$; at $1340 \mathrm{~cm}^{-1}$ could be related to rocking vibration of aromatic $\mathrm{CH}$; at $1291 \mathrm{~cm}^{-1}$ was not identified; at $1209 \mathrm{~cm}^{-1}$ would be due to the stretching vibration of $(\mathrm{O}-\mathrm{CH} 3)$; the band at $1149 \mathrm{~cm}^{-1}$ was not identified; the band at $1080 \mathrm{~cm}^{-1}$ could possibly be related to the stretching vibration of $(\mathrm{C}-\mathrm{O}-\mathrm{C})$ [30]. The band at $1045 \mathrm{~cm}^{-1}$ was not identified.

Sage sample's analysis, Figure 5, revealed bands that could be related to lipids [31]: at $3304 \mathrm{~cm}^{-1}$, also possibly related to $\mathrm{OH}$ groups vibrations [20]; at $2980 \mathrm{~cm}^{-1}$ and at $2904 \mathrm{~cm}^{-1}$, also possibly related to ethanol [19], nonetheless, this last band could also be due to asymmetric stretching $\mathrm{CH}_{2}$ vibration of lipids [15]. The band at $2118 \mathrm{~cm}^{-1}$ was not identified. The band at $1644 \mathrm{~cm}^{-1}$ could be related to amide I [31], to carboxylic acid [32] or to stretching $\mathrm{C}=\mathrm{O}$ vibration of proteins [15]. The bands at $1454 \mathrm{~cm}^{-1}$ and at $1418 \mathrm{~cm}^{-1}$ were not identified. The band at $1385 \mathrm{~cm}^{-1}$ could be related to bending symmetric $\mathrm{CH}_{3}(\mathrm{CO})$ vibration of 1 ,8-Cineole [33]. There were bands related to amide III [31]: at $1328 \mathrm{~cm}^{-1}$, probably also due to bending of $\mathrm{CH}_{2}$ vibration, and at $1276 \mathrm{~cm}^{-1}$. The bands at 1086,1044 and $877 \mathrm{~cm}^{-1}$ could be due to carbohydrates [31]. Among these bands, the first two could be related to polysaccharides [15]. The band at $1086 \mathrm{~cm}^{-1}$ could also be due to symmetric stretching of $(\mathrm{C}-\mathrm{O}-\mathrm{C})$ of 1,8 -Cineole [33]; the band at $1044 \mathrm{~cm}^{-1}$ could also be related to $\mathrm{OH}$ groups vibration [32]; and the band at $877 \mathrm{~cm}^{-1}$ could also be due to the stretching vibration of $\mathrm{CH}_{2}$ of 1,8 Cineole [33] or to ethanol [19].

Phenolic compounds are an important group of active compounds in herbals since they act disrupting the bacterium cell wall, interfering with the ATP pool and altering its membrane potential, resulting in bacterium's death [34]. The amount of phenolic compounds was higher in Brazilian propolis than in UK one (p< 0.04). Propolis from tropical zones usually present high phenolic compounds compared to propolis from tempered zones, rich in flavonoids [35]. Pomegranate has amount of phenols similar to propolis. Dragon's blood, followed by sage, presented low amounts of propolis. Both Propolis studied and Pomegranate present amounts of propolis [(210-160) $\mathrm{mg} \mathrm{GA} / \mathrm{g}$ of propolis] close to the amount of phenols found in a propolis extract from Minas Gerais, southeast of Brazil, $\sim 170 \mathrm{mg} \mathrm{GA} / \mathrm{g}$ of propolis [36]. The amounts of phenolic compounds are considerably above the minimum amounts of phenols required by the Brazilian National Agency of Heath Survaillance - ANVISA to certify that it is an effective propolis extract, $0.50 \% \mathrm{w} / \mathrm{w}$ [37]. Regarding Pomegranate, the amount of phenolic compounds obtained in this work were above Pomegranate plants extracts from Tunisia [38], but below the amount of phenols in Iranian Pomegranate [14]. Dragon's' Blood presented low amounts of phenols $(\sim 85 \mathrm{mg} / \mathrm{g})$ compared to Dragon's Blood samples from China 
( $\sim 900 \mathrm{mg} / \mathrm{g}$ ) [39] and from Latin America Dragon’s Blood Latex ( 300mg /g) [40]. Sage presented the lowest amounts of phenols among all herbals studied $(\sim 57 \mathrm{mg} / \mathrm{g})$, approximately half of the amount of phenols found in sage extracts from Macedonia [41]. Variation on the amount of phenols is expected, since the quantity of active compounds varies with the plant's origin.

Flavonoids are also an important group of active compounds and their action is by the inhibition of DNA, RNA and proteins synthesis of bacteria and by altering its membrane permeabilization [42]. Regarding flavonoids amounts, propolis from UK presented the highest amounts $(\mathrm{p}<0.05)$, followed by propolis-BR, pomegranate, sage, all with approximately the same amount of flavonoids, and dragon's blood, presenting the lowest amount of flavonoids among all. The herbal with the highest amount of flavonoids among the products studied is Propolis from UK, $35 \mathrm{mg} \mathrm{Q} / \mathrm{g}$ of propolis dry extract. The amount of flavonoids in UK propolis is in the range of flavonoids found in samples from Poland [43]. Brazilian propolis presents fewer amounts of flavonoids than the UK one, which could be confirmed by the FTIR. In UK propolis spectrum, several bands related to flavonoids could be found while in Brazilian Propolis were found some bands related to phenols, e.g. caffeic acid band. Classically, propolis from tempered zone is rich in flavonoids and aromatic acids while propolis from tropical zone is rich in phenolic compounds [44]. Nonetheless, the propolis samples fulfil ANVISA's requirement to be considered as effective extracts, both presented amounts of flavonoids higher than $0.25 \% \mathrm{w} / \mathrm{w}$ [37]. Related to pomegranate extract, it was found $(14.93 \pm 1.00) \mathrm{mg} \mathrm{Q} / \mathrm{g}$ of dry extract. This value is below the Yemeni pomegranate extract's flavonoids amount [45] and it is in between the amount of flavonoids found in Tunisian's pomegranate seed extract, $(6.79 \pm 0.57) \mathrm{mg} / \mathrm{g}$ of dry extract, and its leave's extract, $(26.08 \pm 1.24) \mathrm{mg} / \mathrm{g}$ of dry extract [38]. Regarding sage, the amount of flavonoids can be considered low or, at least, it is below the values found in sage from Macedonia [41]. Dragon's blood present the lowest amount of flavonoids among all products studied. Its amount of flavonoids $(3.03 \pm 0.04) \mathrm{mg} \mathrm{Q} / \mathrm{g}$ of dry extract is considerably below the amount of flavonoids in Dragon's blood from China, $(43.59 \pm 2.45) \mathrm{mg} / \mathrm{g}$ of dry extract [39].

The DPPH scavenging activity is correlated to the antioxidant activity of the herbals. Free radicals are reactive oxygen species (ROS), produced by human cells in wounds when there is an inflammatory process. ROS excess can cause oxidative stress, which can cause damage to cells or even cells death. Antioxidant substances can quench ROS and avoid cell damage / death [46]. DPPH works as a free radical and the herbals hability to scavenge the DPPH radicals shows the herbals' antioxidant activities. The DPPH activity of UK propolis, Pomegranate and Dragon's blood are identical $(\mathrm{p}>0.05)$. It can be noticed that UK propolis antioxidant activity $(\sim 92 \%)$ is higher than that of Polish propolis $(\sim 60 \%)$, both from tempered zone [47]. The antioxidant activity of pomegranate extract is close to the antioxidant activity of high concentration pomegranate extracts [45] [48]. Dragon's blood anti-oxidant activity (concentration of $1 \mathrm{mg} / \mathrm{ml}$ ), $\sim 94 \%$, can be compared to the antioxidant activity of $0,3 \mathrm{mg} / \mathrm{ml}$ Dragon's blood resin extracts, $\sim(80-90) \%$ [7]. Brazilian propolis has, in comparison, low antioxidant activity $(\sim 88 \%)$, nonetheless, in the range of other Brazilian propolis' DPPH scavenging activities [49]. Sage $(1 \mathrm{mg} / \mathrm{ml})$ has the lowest DPPH scavenging activity, $\sim 82 \%$, activity comparable to the DPPH scavenging activity of $50 \mu \mathrm{g} / \mathrm{ml}$ sage ethanolic extracts, $\sim 81 \%$ [50]. Apparently, the antioxidant activity of all herbals in the concentration of $1 \mathrm{mg} / \mathrm{ml}$ can be considered high.

The antioxidant activity can be traditionally correlated with the amount of phenolic compounds in plants. Phenolic compounds and flavonoids can be considered secondary metabolites. Phenolic compounds would be the ones directly correlated with the antioxidant activity, but flavonoids could also be responsible for this effect. Their mechanism of action is related to their ability to donate hydrogen and scavenging freeradicals. The ability to scavenge the free radicals allows these compounds to interact with reactive oxygen species (ROS) which can lead to oxidative stress and damage to tissues. Phenolic compounds and flavonoids, by reacting with ROS, avoid oxidative stress that could delay wound healing. They thereby stimulate the wound healing. In addition, other metabolites in plants besides phenols and flavonoids could contribute to the antioxidant activity and wound healing. The results found in the present work could be related to phenols, flavonoids and other metabolites [51] [52].

It can be observed that, with respect to antioxidant activity, UK propolis and pomegranate tincture are promising. Both present approximately the same amount of phenols $(\sim 164 \mathrm{mg} / \mathrm{g})$, although the flavonoids amount differed. Both products presented the same DPPH activity, even though the amount of flavonoids in UK propolis was double that in pomegranate. It could be observed that phenolic compounds would probably be the ones responsible by pomegranate's antioxidant activity while flavonoids would be important for the antioxidant effect of UK propolis. In dragon's blood, phenols and flavonoids could not be the only ones responsible for the antioxidant activity (regarding their amounts), probably indicating that other non-quantified metabolites would be responsible. These three products can be considered to be the most promising among the ones studied. 


\section{CONCLUSIONS}

Five natural products were analysed in this study. All five products were found to contain Phenols and flavonoids and to present antioxidant activities. Of the products studied, Brazilian propolis and pomegranate were found to be rich in phenolic compounds, although the phenol content in the UK propolis was also high. As would be expected in products from temperate zones UK propolis was found to be rich in flavonoids, as confirmed by FTIR analysis. All products presented high antioxidant activities in the concentrations studied, with the antioxidant activities of Dragon's blood, UK propolis and pomegranate being the highest. Phenolic compounds are ostensibly responsible for pomegranate's antioxidant activity while flavonoids would presumably contribute significantly to the antioxidant activity of UK propolis. In dragon's blood other nonquantified metabolites (besides phenols and flavonoids) are most likely responsible for the anti-oxidant activity.

\section{ACKNOWLEDGEMENTS}

The authors thank CNPq, FAPERJ and CAPES for the financial support.

\section{BIBLIOGRAPHY}

[1] KUMAR, B., VIJAYAKUMAR, M., GOVINDARAJAN R., et al. "Ethnopharmacological approaches to wound healing - Exploring medicinal plants of India”, Journal of Ethnopharmacology, v. 114, n. 2, pp. 103-113, Nov. 2007.

[2] KLASEN, H. "Historical review of the use of silver in the treatment of burns. I. Early uses", Burns, v. 26, n.2, pp. 117-130, Mar. 2000.

[3] ULKUR, E., ONCUL, O., KARAGOZ, H., et al. "Comparison of silver-coated dressing (ActicoatTM), chlorhexidine acetate $0.5 \%$ (BactigrassR), and fusidic acid $2 \%$ (FucidinR) for topical antibacterial effect in methicillin-resistant Staphylococci-contaminated, full-skin thickness rat burn wounds", Burns, v. 31, n. 7, pp. 874-877, Nov. 2005.

[4] VUJANOVIC S., VUJANOVIC, J. "Bioresources in the pharmacotherapy and healing of burns: A minireview”, Burns, v. 39, n. 6, pp. 1031-1038, Sep. 2013.

[5] GASPAR, A., CRACIUNESCU, O., TRIF, M., et al. "Antioxidant and anti-inflammatory properties of active compounds from Arnica Montana L.”, Romanian Biotechnological Letter, v. 19, n. 3, pp. 93539365, Jan. 2014.

[6] OLIVEIRA, I., LIMA, J., SILVA R., et al. "Triagem da atividade antibacteriana in vitro do látex e extratos de Croton urucurana Baillon”, Brazilian Journal of Pharmacognosy, v. 18, n. 4, pp. 587-593, Oct. 2008.

[7] GUPTA D., GUPTA, R. "Bioprotective properties of Dragon's blood resin: In vitro evaluation of antioxidant activity and antimicrobial activity", BMC Complementary and Alternative Medicine, v. 17, n. 11, pp. 1-9, Feb. 2011.

[8] ADEWUMI A., OGUNJINMI, A. "The healing potential of honey and propolis lotion on septic wounds”, Asian Pacific Journal of Tropical Biomedicine, v. 1, n. 1, pp. S55-S57, Sep. 2011.

[9] SEHN, E., HERNANDES, L., FRANCO, S., GONÇALVES C., BAESSO, M. "Dynamics of reepithelialisation and penetration rate of a bee propolis formulation during cutaneous wounds healing", Analytica Chimica Acta, v. 635, n.1, pp. 115-120, Jan. 2009.

[10] PEREIRA, A., ANDRADE, S., SWERTS, M., et al. "First in vivo evaluation of the mutagenic effect of Brazilian green propolis by comet assay and micronucleus test", Food and Chemical Toxicology, v. 46, n. 7, p. 2580-2584, Apr. 2008.

[11] BORGES, J., TAGLIAMENTO, M., SILVA, A., et al. "Development and characterization of orallydisintegrating films for propolis delivery", Food Science and Technology, v. 33, suppl. 1, pp. 28-33, Feb. 2013.

[12] MIGUEL, M., NUNES, S., DANDLEN, S., et al. "Phenols and antioxidant activity of hydro-alcoholic extracts of propolis from Algarve, south of Portugal", Food and Chemical Toxicology, v. 48, n. 12, pp. 3418-3423, Sep. 2010. 
[13] MIRZOEVA, O., GRISHANIN, R. CALDER, P. “Antimicrobial action of propolis and some of its components: the effects on growth, membrane potential and motility of bacteria", Microbiological Research, v. 152, n. 3, pp. 239-246, Sep. 1997.

[14] AMJAD, L. SHAFIGHI, M. "Evaluation of Antioxidant activity, phenolic and flavonoid content in Punica granatum var. Isfahan Malas flowers", International Journal of Agriculture and Crop Sciences, v. 5, n. 10, pp. 1133-1139, 2013.

[15] CAPEK, P., HRIBALOVA, V., ŠVANDOVÁ, E., et al. "Characterization of immunomodulatory polysaccharides from Salvia officinalis L.”, International Journal of Biological Macromolecules, vol. 33, n. 1-3, pp. 113-119, Nov. 2003.

[16] BACCARIN, T., MITJANS, M., RAMOS, D., et al. "Photoprotection by Punica granatum seed oil nanoemulsion entrapping polyphenol-rich ethyl acetate fraction against UVB-induced DNA damage in human keratinocyte (HaCaT) cell line", Journal of Photochemistry \& Photobiology, B: Biology, v. 153, pp. 127-136, Sep. 2015.

[17] SÜNTAR, I., AKKOL, E., KELES, H., et al. "A novel wound healing ointment: A formulation of Hypericum perforatum oil and sage and oregano essential oils based on traditional Turkish knowledge", Journal of Ethnopharmacology, v. 134, n. 1, pp. 89-96, Mar. 2011.

[18] PLYLER, E.K. "Infrared spectra of methanol, ethanol, and n-propanol”, Journal of Research of the National Bureau of Standards, v. 48, n.4, pp. 281-286, Apr. 1952.

[19] GUTIERREZ-GONÇALVES, M. E. J., MARCUCCI, M. C. “Atividades Antimicrobiana e Antioxidante da Própolis do Estado do Ceará”, Revista Fitos, v.4, n.1, PP. 81-86, Mar. 2009.

[20] JUNIOR, V., ARRUDA, I., BEMME, L., et al., "Caracterização térmica e espectroscópica de microcápsulas de quitosana incorporada de própolis", Revista Eletrônica da Univar, v. 2, n. 10, pp. 161 $-165,2013$.

[21] BARUD, H., JÚNIOR, A., SASKA, S., MESTIERI, L., et al., “Antimicrobial Brazilian propolis (EPPAF) containing biocellulose membranes as promising biomaterial for skin wound healing", EvidenceBased Complementary and Alternative Medicine, v. 2013, pp. 1-10, May 2013.

[22] SHARAF, S., HIGAZY, A., HEBEISH, A. "Propolis induced antibacterial activity and other technical properties of cotton textiles", International Journal of Biological Macromolecules, v. 59, pp. 408-416, Aug. 2013.

[23] FRANCA, J., DE LUCA, M., RIBEIRO, T., et al., "Propolis - based chitosan varnish: drug delivery, controlled release and antimicrobial activity against oral pathogen bacteria", BMC Complementary and Alternative Medicine, v. 14:478, pp. 1-11, 2014.

[24] MOT, A., SILAGHI-DUMITRESCU, R., SÂRBU, C. "Rapid and effective evaluation of the antioxidant capacity of propolis extracts using DPPH bleaching kinetic profiles, FT-IR and UV-vis spectroscopic data", Journal of Food Composition and Analysis, v. 24, n. 4-5, pp. 516-522, Jun. 2011.

[25] SILVA, A., SILVA, J., DE SOUZA, N., et al., "Membranes from latex with propolis for biomedical applications", Materials Letters, v. 116, n. 1, pp. 235-238, Feb. 2014.

[26] AY, Ç., ÖZCAN, A., ERDOGAN, Y., ÖZCAN, A. "Characterization of Punica granatum L. peels and quantitatively determination of its biosorption behavior towards lead(II) ions and Acid Blue 40", Colloids and Surfaces B: Biointerfaces, v. 100, pp. 197-204, May 2012.

[27] VENKATESWARLU, S., KUMAR, B., PRATHIMA, B., et al. “A novel green synthesis of Fe3O4 magnetic nanorods using Punica granatum rind extract and its application for removal of $\mathrm{Pb}$ (II) from aqueous environment”, Arabian Journal of Chemistry, pp. 1-9, Oct. 2014.

[28] VARDIN, H., TAY, A., OZEN, B., MAUER, L. “Authentication of pomegranate juice concentrate using FTIR spectroscopy and chemometrics", Food Chemistry, v. 108, n. 2, pp. 742-748, May 2008.

[29] EDISON, T., SETHURAMAN, M. "Biogenic robust synthesis of silver nanoparticles using Punica granatum peel and its application as a green catalyst for the reduction of an anthropogenic pollutant 4 nitrophenol", Spectrochimica Acta Part A: Molecular and Biomolecular Spectroscopy, v. 104, pp. 262 264, Mar. 2013. 
[30] KOPERSKA, M., ŁOJEWSKI, T., ŁOJEWSKA, J. "Vibrational spectroscopy to study degradation of natural dyes. Assessment of oxygen-free cassette for safe exposition of artefacts", Analytical and Bioanalytical Chemistry, v. 399, n. 9, pp. 3271-3283, Mar. 2011.

[31] SKOTTI, E., KOUNTOURI, S., BOUCHAGIER, P., et al., "FTIR spectroscopic evaluation of changes in the cellular biochemical composition of the phytopathogenic fungus Alternaria alternata induced by extracts of some Greek medicinal and aromatic plants", Spectrochimica Acta Part A: Molecular and Biomolecular Spectroscopy, v. 127, pp. 463-472, Jun. 2014.

[32] RODRÍGUEZ-TORRES, A., VALLADARES-CISNEROS, M., GONZALEZ-RODRÍGUEZ, J. "Use of Salvia officinalis as green corrosion inhibitor for carbon steel in acidic media", International Journal of Electrochemical Science, v. 10, pp. 4053 - 4067, 2015.

[33] SCHULZ, H., OZKAN, G,. BARANSKA, M, et al., "Characterisation of essential oil plants from Turkey by IR and Raman spectroscopy”, Vibrational Spectroscopy, v. 39, n. 2, pp. 249-256, Oct. 2005.

[34] TIWARI, V., ROY, R., TIWARI, M. “Antimicrobial active herbal compounds against Acinetobacter baumannii and other pathogens”, Front. Microbiol., vol. 6, pp. 1-11, Jun. 2015.

[35] SILVA, J., SOUZA, M., MATTA, S., et al., "Correlation analysis between phenolic levels of Brazilian propolis extracts and their antimicrobial and antioxidant activities", Food Chemistry, v. 99, n. 3, pp. 431-435, 2006.

[36] CABRAL, I., OLDONI, T., ALENCAR, S., et al., "The correlation between the phenolic composition and biological activities of two varieties of Brazilian propolis (G6 and G12)", Brazilian Journal of Pharmaceutical Sciences, v. 48, n. 3, pp. 557-564, Jul. 2012.

[37] BRAZIL, "Diário Oficial da União", Governo Federal do Brasil, Brasília, n. 16, 26 Jan. 2001.

[38] ELFALLEH, W., HANNACHI, H., TLILI, N., et al., "Total phenolic contents and antioxidant activities of pomegranate peel, seed, leaf and flower", Journal of Medicinal Plants Research, v. 6, pp. 4724-4730, Aug. 2012.

[39] LUO, Y., WANG, H., XU, X., et al., "Antioxidant phenolic compounds of Dracaena cambodiana", Molecules, v. 15, n. 12, pp. 8904-8914, Jun. 2010.

[40] DE MARINO, S., GALA, F., ZOLLO, F., et al., "Identification of minor secondary metabolites from the latex of Croton lechleri (Muell-Arg) and evaluation of their Antioxidant Activity", Molecules, v. 13, pp. 1219-1229, 2008.

[41] ALIMPIĆ, A., OALDJE, M., MATEVSKI, V., et al., "Antioxidant activity and total phenolic and flavonoid contents of Salvia amplexicaulis Lam. extracts", Archives of Biological Sciences, v. 66, n. 1, pp. 307-316, 2014.

[42] DZOYEM, J., HAMAMOTO, H., NGAMENI, B., et al., "Antimicrobial action mechanism of flavonoids from Dorstenia Species", Drug Discoveries \& Therapeutics, vol. 7, n. 2, pp. 66-72, Apr. 2013.

[43] SOCHA, R., GAŁKOWSKA, D., BUGAJ, M., et al., "Phenolic composition and antioxidant activity of propolis from various regions of Poland", Natural Product Research, v. 29, n. 5, pp. 1-9, Sep. 2014.

[44] RIGHI, A., NEGRI, G., SALATINO, A. "Comparative chemistry of propolis from eight Brazilian localities", Evidence-Based Complementary and Alternative Medicine, v. 2013, pp. 1-15, Mar. 2013.

[45] SHIBAN, M., AL-OTAIBI, M., AL-ZOREKY, N. "Antioxidant Activity of pomegranate (Punica granatum L.) fruit peels”, Food and Nutrition Sciences, v. 3, n. 7, pp. 991-996, Jul. 2012.

[46] POLJSAK, B., ŠUPUT, D., MILISAV, I. "Achieving the balance between ROS and antioxidants: when to use the synthetic antioxidants", Oxidative Medicine and Cellular Longevity, v. 2013, pp. 1-12, 2013.

[47] TYSZKA-CZOCHARA, M., PAŚKO, P., RECZYŃSKI, W., et al., "Zinc and propolis reduces cytotoxicity and proliferation in skin fibroblast cell Culture: total polyphenol content and antioxidant capacity of propolis", Biological Trace Element Research, v. 160, n. 1, pp. 123-131, Jun. 2014.

[48] JARDINI, F., PINTO, J., MENDONÇA, R., et al., "Avaliação da atividade antioxidante do extrato hidroalcoólico da romã (Punica granatum) sobre células da linhagem Caco-2", Ciência e Tecnologia de 
Alimentos, v. 27, pp. 80-83, Aug. 2007.

[49] ALVES, E., KUBOTA, E. “Conteúdo de fenólicos, flavonoides totais e atividade antioxidante de amostras de própolis comerciais", Revista de Ciências Farmacêuticas Básica e Aplicada, v. 34, n. 1, pp. 37-41, 2013.

[50] RASMY, N., HASSAN, A., FODA, M., EL-MOGHAZY, M. "Assessment of the antioxidant activity of sage (Salvia officinalis L.) extracts on the shelf life of mayonnaise", World Journal of Dairy \& Food Sciences, v. 7, n. 1, pp. 28-40, 2012.

[51] SILVA, J., SOUZA, M., MATTA, S., et al., "Correlation analysis between phenolic levels of Brazilian propolis extracts and their antimicrobial and antioxidant activities", Food Chemistry, v. 99, n. 3, p. 431435, 2006.

[52] SHARMA, P., JHA, A., DUBEY, R., PESSARAKLI, M. "Reactive oxygen species, oxidative damage, and antioxidative defense mechanism in plants under stressful conditions", Journal of Botany, v. 2012, pp. 1-26, 2012. 